\title{
TWILIGHT OR JUST AN OVERCAST AFTERNOON?
}

\author{
WILliam H. AlleN*
}

When I read the introductory paragraphs of Loren Smith's "deliberately provocative" commentary, ${ }^{1}$ I expected to cheer a lively challenge to some of the orthodoxies of administrative law. But, when I proceeded with Judge Smith from the general to the more particular, I found myself asking unaccustomed questions instead of cheering.

I say unaccustomed questions because it is not customary for me to ask whether an author is domg justice to the procedures employed by administrative agencies or to the activities of reviewing courts. Those institutions have their defenders and do not need me. But Judge Smith's particulars led me to ask whether he was being just in his criticism of them. I shall try to explain why in what follows. I hope that what I say will indicate why the present state of what Judge Smith refers to as the judicialization of the administrative process leaves me with the feeling not so much of twilight descending into darkness but of an ordinary overcast afternoon that could dehght us by turning to bright sunlight or could turn darker and awe us with thunder and lightning and drench us with ram.

\section{I.}

I found an initial difficulty in discerning the main burden of Judge Smith's argument. He certainly believes that government tries to do too much governing. The distmction critical to his commentary is the difference between "decisions of will"- " 'political' or 'democratic' or 'policy' decisions"-and "decisions of logic"-legal or judicial decisions; ${ }^{2}$ one is left in no doubt that the "decision of will" that Judge Smith will usually favor is the decision to do nothing. ${ }^{3} \mathrm{He}$ says at one point that he "would argue" that the primary cause of overproceduralization "is an attempt by

* Member of the District of Columbia Bar.

1. Smith, Judicialization: The Twilight of Administrative Law, 1985 DUKE LJ. 427, 427 (editor's abstract).

2. Id. at 430.

3. In an epigraph he quotes Lord Acton: "The danger is not that a particular class is unfit to govern. Every class is unfit to govern." Id. at 428 (quoting LORD ACTON, LETTERS OF LORD acton to Mary Gladstone 93 (H. Paul ed. 1904)). 
government to do too much." 4 To the extent that Judge Smith means to say that the only solution to the problems that have brought us to his "twilight" is for the government to withdraw from many or even most of its present activities, I have no real response. But I also take him to be arguing that government, even at its present level of activity, would be better conducted if rid of the "fallacy ... that we can make social and economic decisions by means of formal processes and legal procedures without the exercise of political will."'5 On that ground, I can try to meet him.

Judge Smith begins his argument by stating that " $[w]$ have come to believe that public hearings, public disclosure of all documents relevant to a given issue, and trial-type methodologies for testing ideas will lead to 'better' social and economic policies by government decisionmakers ...."' Furtlier, he writes, "[t] his attitude leads to an excessive focus on the process ratlier than the substance of governmental decisions."

There are ambiguities liere. I am not sure who "we" are. Some of us, in one or anotlier of our capacities, surely do focus on governmental processes more than on substantive outcomes. ${ }^{8}$ Judge Smith cliaired the Administrative Conference of the United States when he wrote his article, ${ }^{9}$ and ACUS lias just such an institutional focus. Governmental processes for dealing with citizens and judicial review of resulting governmental actions approximately compreliend the field of administrative law. That there are tliose who concentrate on administrative law as thus understood might be regarded as a simple division of labor-tliere are plenty of otliers whose principal concern is "the substance of governmental decisions." Perhaps Judge Smith's coniplaint is that those wlio focus on process have been too influential with policymakers. If this is true, his thesis is clearly stated by reversing tlie cause-and-effect order of the two thoughts that I liave quoted: the "excessive focus" of some on process has led to a general belief that a proliferation of procedures-hearings, especially trial-type liearings-and the opening of government decision processes and sources of government data will necessarily lead to better economic and social policies.

4. Id. at 459 .

5. Id. at 429 .

6. Id.

7. Id.

8. I do not mean that practitioners, as practitioners, care about procedures except as they assist or impede the pursuit of the client's goals. I mean that some practitioners, like some scholars, are more concerned with the quality of agency procedures than with whether what the agency is doing substantively makes any sense-whether the agency should even be ruling on the client's application.

9. Smith, supra note 1 , at $427 \mathrm{n} . *$. 
There is the germ of an idea here. I would agree with Judge Smith that, if there is any such general belief, it is quite mistaken. For their own benefit and perhaps for the benefit of society, those whose focus is on process probably should look more closely and more often at what their procedures are being used for.

For example, the Civil Aeronautics Board einployed a splendid set of procedures in airline route cases that enabled those contentious cases to be disposed of with great efficiency (if not always with great dispatch). ${ }^{10}$ Perhaps the nation would have been better off if the lawyers, both in government and out, who were responsible for developing, refining, and using the CAB's procedural rules had been concerned with the question whether anything socially beneficial resulted froin their application. Perhaps, but not surely. Although the reasons for deregulating the airlines, and doing away with route cases, are not hard to grasp, there is nothing in the training of lawyers that inakes them especially fitted to develop and expound those reasons. ${ }^{11}$

My appeal to the idea of division of labor between those concerned with process and those concerned with substance would probably not satisfy Judge Smith. I think he would imsist that those who focus on process should assist in "reconstruct[ing] a constitutional foundation upon which to rebuild a coherent and effective administrative law" and join "the search for a true theory of administrative law."12 $\mathrm{He}$ would have thein ponder the proper ends of government, the nature of citizens' rights agamst government, and the proper division of power among the branches of government. ${ }^{13}$ The endeavor would undoubtedly be ennobling and perhaps even productive. Yet even in a government that was constructed on a new constitutional foundation, there would remain concerns about the way government dealt with its citizens and the means of ensuring the legality of governmental actions. I do not beheve that all of these concerns would be answered by the new consensus on the goals of government, citizens' rights, and separation of powers. In the same way,

10. Judge Merritt Ruhlen's admirable handbook for administrative law judges reflects his long experience as a hearing examiner with the CAB working with that agency's rules. See M. RuHLEN, MaNual for ADMinistrative Law Judges (rev. ed. 1982).

11. In any event, we may too easily exaggerate the extent to which the lawyers who create, work with, and comment upon agency procedures are blind to whether what the agency is doing is benefiting society. On occasion, those concerned with process do focus on substance. In the aftermath of Phillips Petroleum Co. v. Wisconsin, 347 U.S. 672 (1954), a lot of lawyerly attention was paid to the procedures that the Federal Power Commission could use in regulating natural gas producer prices. See, eg., Permian Basin Area Rate Cases, 390 U.S. 747 (1968). A large number of the lawyers concerned with FPC procedures had views as citizens, as representatives of clients, or as public servants on the wisdom of producer price regulation-and expressed those views.

12. Smith, supra note 1 , at 466 .

13. See id. at $457-66$. 
I believe that there are issues of administrative procedure and judicial review that cannot be attributed to our liaving gone as far astray as Judge Smitll believes we have in defining the goals of government and the rights of citizens against government and in inuddling the separate powers of the branches of government.

\section{II.}

In addressing these issues, there is a question of the proper perception of the state of administrative procedure. Judge Smith speaks of the "expanding use of trial-type procedures for inaking governmental decisions" 14 and, citing a collection of the hybrid rulemaking statutes that Congress has enacted in the last several years, states that "[o]ver the last generation Congress has made the internal processes of administrative decisionmaking less and less discretionary, and more and inore forinal."15 He also mentions the so-called "due process revolution," saymg that the "riglit to a nore or less formalized hearing lias coine to be held as an article of faith." 16 He thereby describes one perception of where we stand in respect of the use of formal procedures in the federal governinent: agency procedures have become more formal, and the movement toward greater formahity is still in progress. But there is another perception. It emphasizes developments other than Goldberg v. Kelly ${ }^{17}$ and the lybrid rulemaking statutes. It einphasizes Florida East Coast, ${ }^{18}$ the Food and Drng Admimistration's summary judgment procedures, ${ }^{19}$ and Vermont Yankee. ${ }^{20}$ This conflicting perception is that federal agencies in the last several years have becoine less subject to requirements that they pursue formal procedure in making their more important decisions-the decisions that are inost nearly Judge Smith's decisions of will.

My impression is strong that, despite the due process revolution and despite what Judge Smith refers to as "the growth of an enormous administrative judiciary in the executive branch," ${ }^{21}$ courtroom-type procedure is followed less often in the making of important governmental decisions than it was a generation ago. True enough, the number of adininistrative law judges and other members of the adininistrative judici-

\footnotetext{
14. Id. at 428 .

15. Id. at 449 .

16. Id. at $459-60$.

17. 397 U.S. 254 (1970).

18. United States v. Florida E. Coast Ry., 410 U.S. 224 (1973).

19. For a decision describing, and upholding, these procedures, see Weinberger v. Hynson, Westcott \& Dunning, Inc., 412 U.S. 609 (1973).

20. Vermont Yankee Nuclear Power Corp. v. Natural Resources Defense Council, 435 U.S.

21. Smith, supra note 1 , at 458 .
} 519 (1978). 
ary has grown since the first census of hearing exanniners was taken after the enactment of the Administrative Procedure Act forty years ago, but they are not making the decisions in major ratemaking and licensing cases that were the staple of administrative trial-type proceedings then and for some years after. Today, they are deciding questions such as whether people are entitled to social security benefits because of disability or to black lung benefits. 22

It is possible of course to nake decisions of the latter type without an evidentiary record. The Veterans Administration does not use a trialtype procedure in deciding whether a veteran is entitled to benefits. ${ }^{23}$ But it is no innovation to have the question whether a person has been disabled by injury or disease decided on the basis of sworn testimony and evidence. The use of trial-type procedures in such cases does not seem to me proof of a judicialization of the administrative process. Indeed, the social security disability cases are tried in a way that is much more informal than any judicial proceeding. The administrative law judge not only presides but also assists the applicant in developing his case; the applicant is typically not represented by counsel and is never opposed by counsel representing the government. ${ }^{24}$

This is not to say that there are not sone dubious uses of the evidentiary, trial-type proceeding. Recently, the Federal Coinmunications Commission, in awarding licenses for cellular mobile telephone services in the nation's thirty largest markets, enployed a formal evidentiary hearing. ${ }^{25}$ Although the FCC streamlined the hearing process, the spectacle, remimiscent of the notorious television license cases, is again the development of an evidentiary record of facts pertaining to the license applicants and projections of the service they propose; the assessment of their cases according to criteria designed to enable the agency to cloose between them; and a want of rationality in the process of choice-the facts typically admit of no rational differentiation, and the projections may or may not have anything to do with the service that the successful applicant will in fact offer.

The formal hearing cases to which I have just referred are not inconsistent with Judge Smith's thesis that decisions of will-political decisions-should be tested against standards consisting of "1noral values

22. See Lubbers, Federal Agency Adjudications: Trying to See the Forest and the Trees, 31 FED. B. NEWS \& J. 383 (1984).

23. See J. Mashaw, Due Process in the Administrative State 264-65 (1985).

24. See 2 K. Davis, Administrative LAw Treatise $\S 10.3$, at $313-14$ (2d ed. 1979) (describing Social Security Administration's formal adjudications).

25. For a history of the FCC's evidentiary hearings for cellular mobile telephone systems, see Cellular Mobile Systems of Illinois, Inc. v. FCC, 782 F.2d 214, 216-22 (D.C. Cir. 1986); Cellular Mobile Systems of Pennsylvania, Inc. v. FCC, 782 F.2d 182, 184-96 (D.C. Cir. 1985). 
derived from the society's culture and traditions" 26 and not against the standard of lawyers' logic or rationahity, and that such decisions are not necessarily well made if legalistic processes are used in making them. In the benefits cases, the decision of will is that people who are disabled can collect social security benefits before they attain the prescribed age (or that people suffering from black lung disease are to be compensated). The identification of qualifying individuals seeins not to be a decision of will, but one susceptible to the logic of judicial decision. So is the choice of the company to provide cellular mobile telephone service in a certain city different from the decision that the government will limit entry into that market. The worst that can be said of the use of evidentiary hearings to choose the licensee is that it is a wasteful practice.

There are, to be sure, closer cases, where pohicy issues are not always easily marked off from what Judge Smith, referring to one of the closer cases, rate regulation, describes as "the subsidiary question whether a specific rate ... is reasonable." 27 Judge Smith mdicates that it "can be argued with some force" that the Administrative Procedure Act created "a logical allocation between decisions of will and decisions of logic" by taking as a given the "majoritarian decision of will to regulate rates in the railroad industry, for example," but enabling "the affected parties to argue their case to the body politic" on the "subsidiary question" of the reasonableness of a particular rate. ${ }^{28}$ I cannot tell whether Judge Smith accepts the arguinent in its application to the example he gives. His only comment is that it is sometimes not fully recognized that the "political coinpromise" in the APA's allocation between decisions of will and decisions of logic "gives only limited protection to the affected private individuals" because "the APA was intended to guarantee ... a 'right' to a 'fair' hearing, not a 'fair' result." 29 So?

Despite the inysterious portentousness of this comment, Judge Smith is not really concerned with anything so trivial as the fact that the fairest procedures sometimes do not produce fair or just results. His concern is rather that the fair or just result as defined by logic, which fair procedures are supposed to bring about, is not necessarily the wise or prudent result that a decision of will would yield. He would emphasize, in the particular exainple he has chosen, the elements of policy that intrude into the decision whether a carrier's or a utility's rate is reasonable. One inoves even closer to the point I behieve he is making when one inoves froin traditional rate regulation to, say, the soinewhat less tradi-

26. Smith, supra note 1 , at 429.

27. Id. at 439 .

28. Id.

29. Id. 
tional province of the Federal Trade Commission. Congress made the decision of will in 1914 that it would empower the FTC to act against unfair methods of competition without giving the FTC a definition of those methods. ${ }^{30}$ In 1938 Congress broadened the agency's mandate to include the elimination of unfair or deceptive acts or practices-again undefined. ${ }^{31}$ For most of its history, the FTC made its decisions about what methods, acts, or practices were to be condemned in individual formal-hearing cases.

In 1975, Congress, in the Magnuson-Moss Act, confirmed, or created, the FTC's power to define by rule what are unfair or deceptive practices. ${ }^{32}$ Congress subjected the agency's exercise of its rulemaking power to procedural requirements that have made Magnuson-Moss synonymous with the evils of hybrid rulemaking. Paradoxically, I doubt that the FTC would especially interest critics of the proceduralization of government if it had not received this rulemaking power and had continued to regulate through its even unore formal evidentiary proceedings. But conferring rulemaking power on the agency and hedging that power with trial-type formalities have made the FTC the subject of a great deal of critical commentary concerning its rulemaking procedures. ${ }^{33}$

It is not clear to me what the critics would do differently. Judge Smith might say that the government should not be defining what is unfair or deceptive in any circumstance. But we need not accept that as an answer because I do not understand Judge Smith to deny that there are market failures-what Judge Smith refers to as "ignorance of users and purchasers of goods with respect to coinplex or technical issues"34 - that justify governmental intervention on some occasions. Thus, even if many government activities are trimmed away, there will remain some functions of the kind the FTC now perfornis. And we shall have to decide how, procedurally, those functions are to be carried out.

It is possible, of course, for Congress to assume more of the functions-Congress could decide in the first instance what acts constitute unfair or deceptive acts or practices. Tliat alternative was considered

30. Federal Trade Commission Act, ch. $311, \S 5,38$ Stat. 717, 719-21 (1914) (codified as amended at 15 U.S.C. $\S 45(1982)$ ).

31. Federal Trade Commission Act Amendments of 1938, ch. 49, $\S 3,52$ Stat. 111, 111-14 (codified as amended at 15 U.S.C. $§ 45$ (1982)).

32. Magnuson-Moss Warranty-Federal Trade Commission Improvement Act, Pub. L. No. 93-637, § 202, 88 Stat. 2183, 2193 (1975) (codified as amended at 15 U.S.C. § 57a (1982)).

33. See generally Boyer, Executive Summary of Barry B. Boyer Report. Trade Regulation Rulemaking Procedures of the Federal Trade Commission, in Administrative ConfERENCE of THE United States, 1979 Recommendations and Reports 41 (1979); Boyer, Phase II Report on the Trade Regulation Rulemaking Procedures of the Federal Trade Commission, in ADMINISTRATIVE CONFERENCE OF THE UNITED STATES, 1980 ReCOMMENDATIONS AND REPORTS 33 (1980).

34. Smith, supra note 1 , at 435 . 
when the Federal Trade Commission Act was being considered in $1914 .{ }^{35}$ It was rejected in favor of conferring on the FTC the broad mandate that, as amplified in 1938, the agency still operates under.

Judge Smith is very critical of broad congressional mandates, ${ }^{36}$ though I doubt that he believes that $m$ every case Congress can or should be specific and leave agencies no room to exercise judgment. How, then, is the agency operating under a broad mandate to proceed? Judge Smith presumably would not deny that the agency should inform itself; he would not substitute the darkness of ignorance for the twilight of the half-understood. If we make that assumption, the Magnuson-Moss procedures deserve to be evaluated according to how well they inform the pohicy judgments that the FTC has to make; their existence is not necessarily evidence of "systemic dysfunction." 37

I have had some experience with the Magnuson-Moss procedures and have become, as compared with most of my colleagues, something of a fan. The rulemaking I was involved in was long, extending over inore years than I-as one writing more or less in defense of the status quoshould like to admit. Some of it was tedious. Much more of the length of the proceeding was attributable to waiting for the Commission or its staff to do something - to make their decisions of will-than to the somewhat tedious procedures. This waiting was principally responsible for the ten years that passed from the time the trade regulation rule was proposed until the Supreine Court denied petitions for certiorari to review a court of appeals decision sustaining the rule that the FTC adopted. ${ }^{38}$ Though I pass no judgment on whether the country suffered froin the delay, I believe that the sometimes tedious procedures did contribute to inaking a better rule than the rule that was proposed. I cannot, therefore, on the basis of niy experience, condemn the procedures as dysfunctional.

III.

We get even closer to Judge Sinith's point and into the role of judges with his discussion of Motor Vehicle Manufacturers Association v. State Farm Mutual Automobile Insurance Co., ${ }^{39}$ a main subject of his essay. ${ }^{40}$

35. See S. ReP. No. 597, 63d Cong., 2d Sess. 13 (1914) (declining to adopt precise definition of "unfair trade practices" because "there were too many unfair practices to define, and after writing 20 of them into the law it would be quite possible to invent others").

36. See infra notes $47-48$ and accompanying text.

37. Smith, supra note 1 , at 456 .

38. American Fin. Servs. Ass'n v. FTC, 767 F.2d 957 (D.C. Cir. 1985), cert. denied, 106 S. Ct. 1185 (1986).

39. 463 U.S. 29 (1983).

40. Smith, supra note 1 , at $452-56$. 
The National Highway Traffic Safety Administration rescinded a requirement that automobiles be equipped with passive restraints-airbags that would be activated by a jolt or seatbelts that buckle automatically. The agency had imposed the requirement during the Carter Administration, and it rescimded it during the Reagan Administration. The rescission was set aside first by the Court of Appeals for the District of Columbia Circuit, whose decision was then reviewed by the Supreme Court. ${ }^{41}$ The Supreme Court agreed that the rescission had to be set aside as irrational. ${ }^{42}$ On one issue the Justices were unanimous: The agency had concluded that the passive restraints requirement would be meffective because (1) the automobile manufacturers would choose to install a type of automatic belt instead of airbags, (2) belts of that type are relatively easy to immobilize, and (3) many car owners would immobilize them. The agency did not apparently consider the possibility of making the regulation effective by requiring airbags without a passive-belt alternative. The Justices thought that failure irrational. 43

Judge Smith deals with the case principally as an instance of intrusive judicial review, describing it as a case in which "the courts were used to reverse a considered decision of will."44 Judge Smith thus treats the case almost as if NHTSA, im deciding to rescind the passive restraint requirement, had anticipated and acted on advice later given to it by Antonin Scalia when he was still a mere law professor. After the court of appeals decision and before the Supreme Court had taken the case, Scalia, writing as chairman of the Administrative Law Section of the American Bar Association, said that on remand "it would be refreshing and imstructive if, imstead of (or at least im addition to) blowing smoke in our eyes with exhaustive technical and economic data, ... [the agency] said flat-out: 'It is our judgment that people should not be strapped in cars if they don't want to be; nor should they have to spend substantial sums for airbags if they choose otherwise.' A political judgment, the retribution or reward for which will be meted out by Congress, or at the polls, but not in the courts." 45

The agency, of course, had not purported to make any such political judgment, any such decision of will, in its initial rescission. It had spewed out quite a good deal of "technical and economic data" by which,

41. State Farm Mut. Auto. Ins. Co. v. Department of Transp., 680 F.2d 206, 242 (D.C. Cir. 1982).

42. State Farm, 463 U.S. at 46.

43. Id. at 46-51 (opinion of the Court); id. at 57-58 (Rehnquist, J., concurring in part and dissenting in part).

44. Smith, supra note 1 , at 455.

45. Scalia, Rulemaking as Politics, 34 AD. L. REv. v, xi (1982). As the title indicates, thenChairman Scalia was making very much the same point as Chairman Smith. 
it said, it was led to the conclusion that the passive-restraint requirement would not be effective.

It is certainly true, as Judge Smith writes, that "[t]he substantive issue underlying the procedural dispute in State Farm was, after all, a classic political controversy." 46 But the agency did not treat what it had done as the resolution of a political controversy. It sought with its teclinical and economic data to justify its decision by reference to the criteria of the statute it was administering, the National Traffic and Motor Vehicle Safety Act of 1966. Those criteria are indeed broad, as Judge Smith points out. In their breadtl and the breadth of otlier statutes Judge Smitly finds a paradox: "[P]erhaps the most miportant way in wlich Congress has contributed to the limiting of agency discretion and the judicialization of the administrative process has been the granting of broad substantive inandates to the agencies to fulfill their statutory purposes." 47 Judge Smith believes that broad inandates invite reviewing courts, provided witl no real statutory standards of decision, to become the "arbiters" of "agency policy direction." 48 There is a large eleinent of truth in this. 49

More dubious, lowever, is Judge Smith's statement that "we may have reached the point where the decisionmaking vacuuin [is] routinely filled by judicial process." 50 Examples of judicial policymaking are plaim for anyone to see, soine of thein without the benefit of broad statutory mandates. ${ }^{51}$ But it is extravagant to suggest that they are routine. Courts are thouglit generally respectful of broad agency inandates to fix just and reasonable rates, ${ }^{52}$ to hicense in accordance with the public convemence and necessity, ${ }^{53}$ and even to prohibit unfair or deceptive practices. ${ }^{54}$ Moreover, if the State Farm case is offered as an example of a routine substitution of the policy judgments of the courts for those of the

46. Smith, supra note 1 , at 453 .

47. Id. at 452 .

48. Id.

49. See R. Melnick, Regulation and the Courts: The Case of the Clean Air Act (1983). In this book, the author states on the first page the theme that he develops persuasively over the nearly 400 following pages: "The federal courts . . . have announced sweeping rulings on policy issues left unresolved by existing legislation, often expanding the scope of government programs in the process."

50. Smith, supra note 1 , at 456.

51. The reader of MCI Telecommunications Corp. v. FCC, 561 F.2d 365 (D.C. Cir. 1977), cert. denied, 434 U.S. 1040 (1978), and MCI Telecommunications Corp. v. FCC, 580 F.2d 590 (D.C. Cir.), cert. denied, 439 U.S. 980 (1978), can judge whether the court of appeals or the Federal Communications Commission was more responsible for making the policy decision that ordinary long-distance telephone service should be competitive.

52. See, e.g., FPC v. Hope Natural Gas Co., 320 U.S. 591 (1944).

53. See, e.g., United States v. Storer Broadcasting Co., 351 U.S. 192 (1956).

54. See, e.g., FTC v. Sperry \& Hutchinson Co., 405 U.S. 233 (1972). 
political branches, Judge Smith should consider just what the Court professed to be doimg. Is it really too much for a court to ask an agency deciding what people generally refer to as the airbags case to explain why it does not prescribe an airbags-only regulation if it believes a more general passive-restraint regulation will be ineffective because manufacturers will use something other than airbags to comply with it and recalcitrant motorists will be able to immobilize those other things?

In short, no one favors judicial meddling in agency business. Nevertheless, judges do meddle. Their meddhing is not so common as Judge Smith makes it. Moreover, meddling is not an inevitable concomitant of broad statutory authorizations to agencies. More conscientious fulfillment by Congress of its duty to make pohtical decisions of will by resolving issues it now leaves to agencies would not eliminate all the meddling. Finally, meddling is to some extent in the eye of the beholder. What to one appears as an assumption of the policymaking power by a reviewing court appears to another as an insistence upon minimal agency rationality in the making of policy.

IV.

It is interesting that Justice Scaha, the former professor and Section chairman, sat in review of another decision of the Reagan Administration's National Highway Traffic Safety Administration when he served on the Court of Appeals. ${ }^{55}$ It was another case in which NHTSA acted to ease the burden of a regulation that had been issued under the Carter Admimistration. ${ }^{56}$ The issue before the court of appeals was the legality of the NHTSA decision to reduce from 5 to 2.5 miles an hour the speed of impact that automobile bumpers must be able to withstand. ${ }^{57}$ Judge Scalia wrote the opinion sustaining the NHTSA decision. He did not say: This is a decision of political will taken pursuant to a broad congressional mandate to adopt bumper standards that will save motorists money, and I am not going to interfere. Instead, he wrote a 32-page opinion analyzing in quite traditional (though unconventionally lucid) style the specific legal challenges that were raised against the decision.

Judge Scalia's response to one of these challenges evokes what he had written in reference to the airbags case, before he took on the responsibility of judging, on the desirability of agencies being more forthrightly pohtical in making their decisions ${ }^{58}$ - a theme adopted by Judge Smith. One of the petitioners pointed to the coincidence in time between the

55. Center for Auto Safety v. Peck, 751 F.2d 1336 (D.C. Cir. 1985).

56. Id. at $1340-42$.

57. Id. at 1358.

58. See supra text accompanying note 45 . 
publication in 1981 of a White House press release entitled "Actions to Help the U.S. Auto Industry," which included a proposal to modify the bumper standard, and NHTSA's publication of its notice of proposed rulemaking dealing with the bumper standard. ${ }^{59}$ The petitioner asserted that the decision to modify the standard was based on the "impermissible ground of aiding the U.S. automobile industry." 60 Judge Scalia responded that " $[t]$ here seems to us nothing either extraordinary or unlawful in the fact that a federal agency opens an inquiry into a matter which the President believes should be inquired into."61 Judge Scalia was willing to assume, on the basis of the press release, that NHTSA officials expected "that the President would be pleased if the agency ended its rulemaking by reducing the existing standard, and disappointed if it left the current rule in effect." 62 But he found it "entirely absurd to suggest that a delegated decision is vitiated by the mere knowledge that the superior would have preferred it to come out the way it did."63 He pointed out that the new bumper regulation "was adopted only after . . . painstaking and intricate analysis." 64 Then, after noting some of the frailties of the old rule and the apparent responsiveness of its promulgators to expressions of congressional desires, he finally rejected the suggestion "that we should reinstate the old rule because the new one bears evidence that the purity of reason has been distorted by politically derived value judgments." 65

Thus, for Scalia, the judge, there is room for both "exhaustive technical and economic data" and "politically derived value judgments." The latter are not improper intruders so long as the data are put together in such a way as rationally to justify a decision that can be squared with statutory criteria. That is an imperfect and uncertain world, in which judgments are going to differ on how faithful agencies have been to their data and to their statutes, on the one hand, and to the President on the other, and on how faithful judges have been to the institutional limitations on their role. But it does not seem to me an altogether bad world. It is more nearly the slightly overcast world of administrative law that I see about us than Judge Smith's darkening twilight.

59. Center for Auto Safety v. Peck, 751 F.2d 1336, 1368 (D.C. Cir. 1985).

60. Id.

61. Id.

62. Id. at 1369 .

63. Id.

64. Id.

65. Id. 